\title{
(2) OPEN ACCESS \\ Adult Langerhans cell histiocytosis of skull in a patient with synchronous papillary thyroid carcinoma and Castleman disease
}

\author{
In Kyeong Kim ำ, ${ }^{1}$ Kyoung Yul Lee ${ }^{2}$
}

${ }^{1}$ Neurosurgery, Kangwon National University Hospital, Chuncheon, Kangwondo, Korea (the Republic of)

${ }^{2}$ Pathology, Kangwon National University Hospital, Chuncheon, Kangwondo, Korea (the Republic of

Correspondence to Professor In Kyeong Kim; deargrape@naver.com

Accepted 5 January 2021

Check for updates

(c) BMJ Publishing Group Limited 2021. Re-use permitted under CC BY-NC. No commercial re-use. See rights and permissions. Published by BMJ.

To cite: Kim IK, Lee KY. BMJ Case Rep 2021:14:e239341. doi:10.1136/bcr-2020239341

\section{SUMMARY}

We report an extremely rare case of adult Langerhans cell histiocytosis (LCH) in a patient with papillary thyroid carcinoma (PTC) and Castleman disease (CD). A 46-year-old man visited our hospital with anaemia; systemic imaging showed an abdominal and a left thyroid mass. Biopsy confirmed CD for the abdominal mass and PTC for the thyroid mass. Two months after, he presented with headache and a right parietal lump. Brain CT and enhanced MRI revealed an osteolytic mass with enhancement in the right parietal skull. Surgical removal and biopsy confirmed the diagnosis of skull LCH. The BRAF mutation was positive on PTC and negative on CD and LCH. We conducted surgical resection only for PTC and LCH; surgical resection with siltuximab for multicentric $\mathrm{CD}$. At the 25-month follow-up, there was no recurrence or progression. We may consider of syndromic nature of these diseases to establish a treatment strategy.

\section{BACKGROUND}

Langerhans cell histiocytosis (LCH) is a benign proliferative disease of the clonal dendritic cells. ${ }^{12}$ This affects the bone, lung, liver, spleen, bone marrow, lymph nodes, thymus, eye and central nervous system. In paediatric patients, the reported LCH incidence is 2.6-5.4 cases per million. ${ }^{3} \mathrm{LCH}$ is very rare in adults as compared with that in children. The estimated incidence of $\mathrm{LCH}$ is $1-2$ cases per million in adults. ${ }^{1}$

Castleman disease $(\mathrm{CD})$ is a non-neoplastic nonclonal lymphoproliferative disorder, characterised by angiofollicular hyperplasia or giant lymph node hyperplasia. ${ }^{4}$ This affects lymph nodes throughout the body.

Papillary thyroid carcinoma (PTC) is the most common subtype of thyroid cancer that develops in thyroid follicular cells; the reported incidence of PTC in the general population is on the rise..$^{5-8}$

Few reports have described cases of patients with coexisting LCH and PTC, LCH and CD or CD and PTC in the same or multiple organs in a synchronous/ metachronous manner. To our knowledge, this is the first report on an extremely rare case of metachronous LCH in a patient with coexisting PTC and CD. We believe that this is the first study to investigate the clinical significance and treatment strategy for patients with these disease combinations.

\section{CASE PRESENTATION}

A 46-year-old man visited our hospital with anaemia that was diagnosed incidentally during a medical examination. Systemic imaging study showed a left intraabdominal mass with a left thyroid mass.
Serum laboratory studies showed reduced haemoglobin $9.3 \mathrm{~g} / \mathrm{dL}$, haematocrit $32.8 \%$, mean corpuscular haemoglobin concentration 28.4 and iron $15 \mu \mathrm{g} / \mathrm{dL}$; normal ferritin $126.6 \mathrm{ng} / \mathrm{mL}$, total ironbinding capacity $256 \mu \mathrm{g} / \mathrm{dL}$ and reticulocyte count 1.19\%; and an increased platelet count $857000 /$ $\mathrm{mm}^{3}$. The serum total protein level was elevated to $8.3 \mathrm{~g} / \mathrm{dL}$, the albumin level was normal at $4.0 \mathrm{~g} / \mathrm{dL}$, and the alkaline phosphatase level was increased to $480 \mathrm{U} / \mathrm{L}$. There was no evidence of monoclonal gammophathy on serum and urine protein electrophoresis. Serological tests for Epstein-Barr Virus (EBV), Human Herpes Virus 8 (HHV-8), Hepatitis $\mathrm{C}$ Virus (HCV) and HIV were negative. Abdominal CT revealed a left intraabdominal mass and paraaortic lymph nodes of variable size accompanied by hepatosplenomegaly. Whole body fluorodeoxyglucose (FDG) positron emission tomography-CT (PET-CT) exhibited intense hypermetabolism of the left thyroid gland and left abdominal mass and the nodules anterior to the iliopsoas muscle (figure 1). Biopsy was performed for the $7.5 \times 5.5 \mathrm{~cm}$ sized abdominal mass that was one of enlarged paraaortic lymph node and diagnosed to CD. Bone marrow aspiration and biopsy were done; there was no evidence of the involvement of haematolymphoid malignancy. Subsequently, left thyroidectomy and isthmectomy were performed for the $2.9 \mathrm{~cm}$ sized left thyroid mass observed on neck CT. The biopsy showed PTC, corresponding to T3N0M0 in the pathological staging system. ${ }^{9} \mathrm{~B}$-type Raf protooncogene serine/threonine kinase (BRAF) V600E mutation was detected using real-time PCR.

Two months thereafter, he developed a progressive headache and a right parietal lump on the scalp. Skull radiography (figure 2A) and brain CT scan (figure $2 \mathrm{~B}$ ) revealed a $2.3 \mathrm{~cm}$ sized osteolytic mass lesion that involved the diploic space of the right parietal skull with a sclerotic bone margin. Gadolinium enhancement brain MRI showed heterogeneous enhancement of the mass with epidural involvement, adjacent dural enhancement and abnormal bone marrow signal intensity at the peripheral area of the mass (figure 2C). Additional whole body FDG PET-CT (figure 3A) and whole body bone scan (figure 3B) showed hypermetabolism and hot uptake only in the right parietal skull area, suggesting single skull metastasis of thyroid cancer. However, skull metastasis in thyroid cancer is very rare, and most cases are termed follicular thyroid carcinoma. Thus, it was necessary to pathological conformation. 


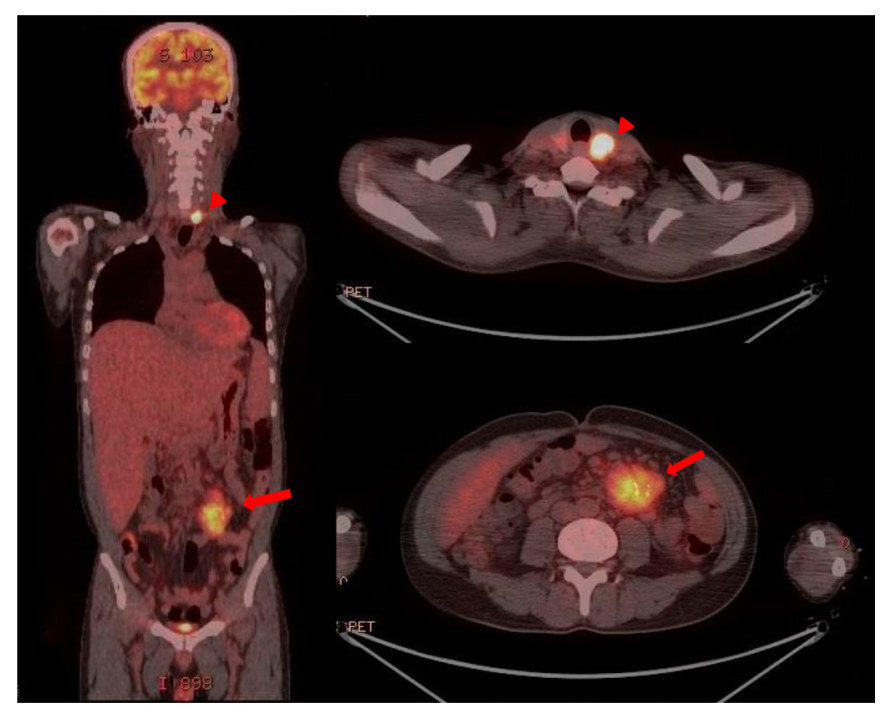

Figure 1 Whole body fluorodeoxyglucose positron emission tomography-CT exhibited intense hypermetabolism of the left thyroid gland (arrow head) and left abdominal mass (arrow) and the nodules anterior to the iliopsoas muscle.

\section{INVESTIGATIONS}

Histological examination for abdominal mass showed angiofollicular lymph node hyperplasia with diffuse plasma cell proliferation in the interfollicular region, compatible with $\mathrm{CD}$ of the plasma cell variant type (figure 4A). Immunohistochemical staining showed CD20 in the follicle centre with CD 138, MUM-1, kappa, lambda in the interfollicular plasma cells with some positive Ig4 cells.

Histological examination for left thyroid mass showed PTC (figure 4B).

Then surgical removal of the right parietal skull mass and histological examination showed diffuse infiltration of the histiocytes with indented, grooved or folded nuclei and eosinophilic cytoplasm (figure 4C). Immunohistochemistry examinations showed positive $\mathrm{S}-100$ and CD1a immunoperoxidase staining (figure 4D) and highlighted the presence of Langerhans cells, consistent with LCH. No BRAF mutation was observed. After the diagnosis of skull $\mathrm{LCH}$, pathological reanalysis was performed to confirm if each condition was present in three different organs or two aetiologies coexisted in the same organ.
A

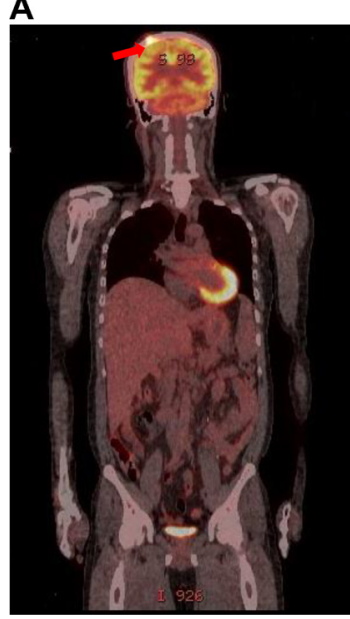

B

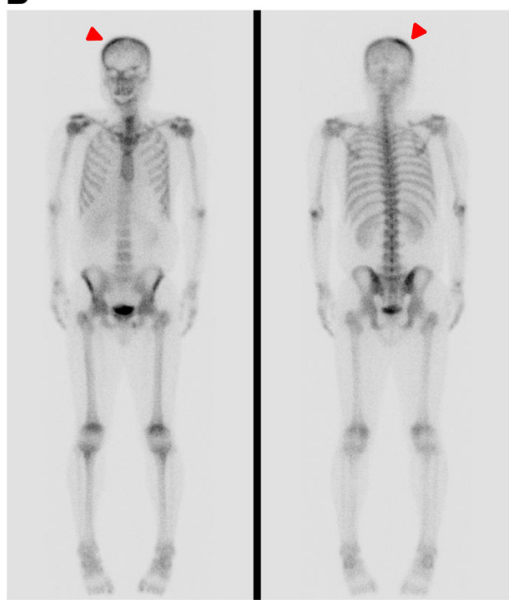

Figure 3 Whole body fluorodeoxyglucose positron emission tomography-CT (A) presenting newly appeared hypermetabolic bone lesion only at the right parietal skull area (red arrow). whole body bone scan (B) showing no other systemic bone uptake except right parietal skull (red arrow head).

Thus, we confirmed that three different aetiologies existed in three different organs.

\section{TREATMENT}

He was treated with three cycles of siltuximab (SYLVANT, $11 \mathrm{mg}$ / $\mathrm{kg}$ over 1 hour via intravenous administration every 3 weeks) for multicentric CD. No any adjuvant therapy for LCH and PTC was administered after gross total resection, and further treatment would be decided later in case of recurrence.

\section{OUTCOME AND FOLLOW-UP}

The LCH and PTC were unchanged and the multicentric CD was stable, with no progression at the 25 -month follow-up.

\section{DISCUSSION}

LCH is a clonal proliferative disease derived from CD1a positive dendritic cells, ${ }^{210}$ that is, mostly observed in paediatric patients; $\mathrm{LCH}$ is rarely noted in adults. ${ }^{1} \mathrm{LCH}$ affects the bone, lung, liver, spleen, bone marrow, lymph nodes, thymus, eye, central nervous system. The aetiology of $\mathrm{LCH}$ remains unclear, and it is debated whether it is a neoplastic disorder, an immune dysregulation
A

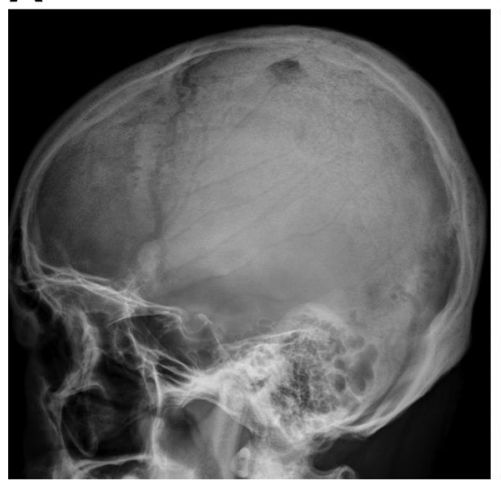

B

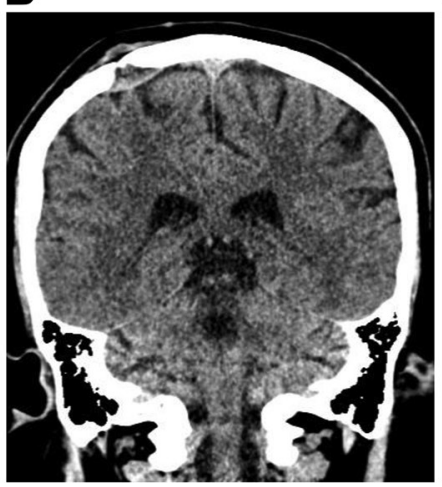

C

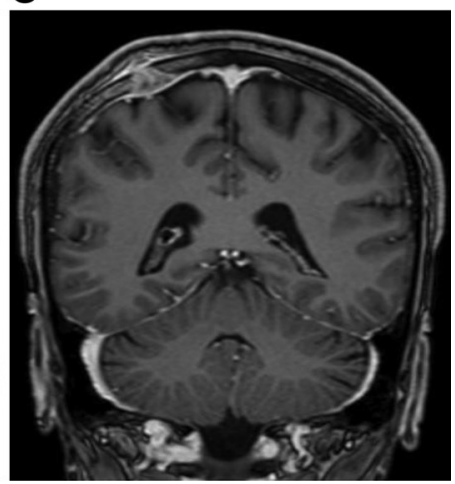

Figure 2 Skull radiography (A) showing right parietal osteolytic lesion. Brain CT (B) showing a $2.3 \mathrm{~cm}$ sized diploic mass of the right parietal bone with sclerotic margin. Gadolinium enhancement brain MRI (C) showing heterogeneous enhancement of the right parietal mass with epidural involvement, adjacent dural enhancement and abnormal bone marrow signal intensity at the peripheral area of the mass. 
A

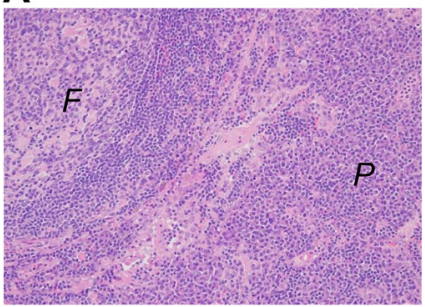

C

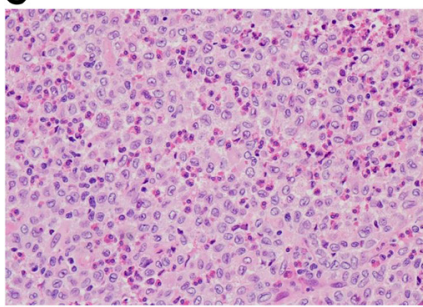

B

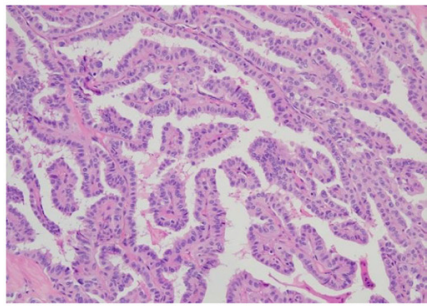

D

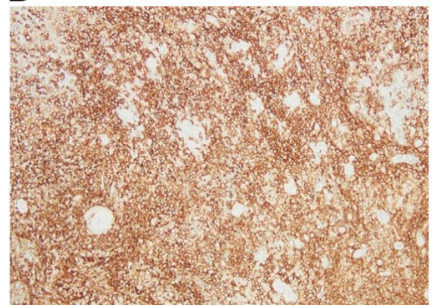

Figure 4 Photomicrographs of the specimen. H\&E $(\times 200)$ of abdominal mass (A) showing angiofollicular lymph node hyperplasia with diffuse plasma cell proliferation in the interfollicular region, compatible with Castleman disease with plasma cell variant type (F: follicle, P: plasma cells of interfollicular area). H\&E stain $(\times 200)$ of thyroid $(B)$ revealing papillary thyroid carcinoma. H\&E stain $(\times 100)$ of skull diploic mass (C) showing infiltration of the histiocytes. Immunoperoxidase stain $(\times 100)$ of skull diploic mass (D) showing expression of CD1 a positive Langerhans cells, consistent with Langerhans cell histiocytosis.

disorder or a reactive disorder. ${ }^{1}$ Conventional histology shows destructive granulomatous lesions containing mononuclear cells with indented nuclei, representing dendritic antigen-presenting Langerhans cells. ${ }^{1}$ Moreover, this condition is characterised with infiltration by lymphocytes and eosinophilic granulocytes with pseudoabscesses. ${ }^{11}$ Immunohistochemistry shows CD1a positive cells, definitively. ${ }^{12}$

$\mathrm{CD}$, also known as angiofollicular or giant lymph node hyperplasia, is a rare non-neoplastic nonclonal lymphoproliferative disorder. ${ }^{4} 12$ This disease affects lymph nodes throughout the body. Furthermore, the aetiology is unclear; however, chronic/ untreated viral infections, such as HCV, EBV, HIV and HHV-8 can induce systemic inflammatory reactions that could lead to CD. ${ }^{13-15}$ EBV is reportedly related to LCH and PTC. ${ }^{16-18}$ Our patient did not show the presence of EBV, HHV-8, HCV or HIV infection. Histologically, CD is categorised into two subtypes as hyaline vascular (HV)-CD and plasma cell (PC)-CD. HV-CD shows the regression of follicles, atrophic germinal centre traversed by the penetrating vessels, and thickening of the mantle zone in small lymphocytes with concentric arrangement. ${ }^{12} 141920$ The interfollicular region exhibits extensive vascular proliferation with perivascular hyalinisation and dysplastic follicular dendritic cell (FDC) network. ${ }^{19-21}$ PC-CD is maintained by hyperplastic follicles accompanied by large mantle zone with a normal FDC network. ${ }^{1419}$ The most characteristic feature is the presence of mature plasma cells in the interfollicular area. ${ }^{19} 22$ Plasma cells are usually polyclonal, ${ }^{192324}$ and rarely monotype immunoglobulin, usually lambda light chain. ${ }^{19} 25$ Immunohistochemical staining shows CD20 at the germinal centre, CD3 at the paracortical zone meaning of the normal distribution of B-cell and T-cell compartment, and CD21, CD23 at germinal centre and in interfollicular area that reveals FDC, while CD31, CD34 represents the blood vessels. ${ }^{14} 2022$ CD138 indicates plasma cells. $^{2022}$

Table 1 summarises the rare cases of coexisting LCH, CD and/or PTC that have been previously reported in the English literature. $\mathrm{LCH}$ is reportedly related to thyroid diseases, such as chronic lymphocytic thyroiditis and thyroid cancer, especially with the most common subtype of PTC. ${ }^{5}$ It can be divided into the following two possibilities: (1) the coexistence of two aetiologies in the thyroid gland and (2) the occurrence of two aetiologies in two different organs synchronously/metachronously. About 15 cases have been previously reported since 1991 for the coexistence of PTC and LCH (cases 1-15 on table 1). ${ }^{56-39}$ Among these cases, $>50 \%$ of the patients had PTC with lymphocytic thyroiditis. It is noteworthy that 15 patients presented with LCH and PTC in the thyroid gland with or without the involvement of $\mathrm{LCH}$ at the other organs; however, our patient had LCH and PTC in different organs, the skull and the thyroid gland, respectively.

Both LCH and PTC are associated with BRAF mutation that is related to aggressive clinical features and poor response to therapy. ${ }^{60}$ Only few studies have reported the BRAF mutation status; one reported a case wherein BRAF V600E mutant-positive LCH and BRAF V600E mutant-negative PTC occurred in the thyroid gland metachronous (Case 10 on table 1 ). ${ }^{35}$ Another patient harboured both PTC and LCH within the thyroid gland and showed BRAF V600K mutant LCH and V600E mutant PTC of two different mutant types (case 15 on table 1). ${ }^{39}$ However, in most previously reported cases, the BRAF mutation status was either not examined commonly or was investigated incompletely. Even in cases where the BRAF mutation status was investigated, it was difficult to understand the interrelationship between BRAF mutation and the cross-occurrence of diseases based on the variable status of BRAF mutation. Future large-sized research with BRAF mutation assessment is necessary to determine whether there is any clinical significance in the co-occurrence of the two aetiologies.

The implications of BRAF mutation have been identified in LCH and PTC; however, the clinical significance of BRAF mutation in $\mathrm{CD}$ remains unclear. In the present case, after BRAF mutant-positive PTC and BRAF mutant-negative LCH were diagnosed, additional BRAF mutation study for CD was performed. This investigation identified BRAF mutant-negative CD. Thus, the pathogenesis of the cross-occurrence of LCH, PTC and CD may not be associated only with BRAF mutation, despite the lack of studies. We need to consider the possibility of genetic variants other than that of the BRAF gene pathway.

To our knowledge, this is the first report of a patient with three disease entities of synchronous CD and PTC with metachronous LCH in different organs. After identifying the coexistence of three different diseases in this patient, a pathological review reaffirmed that each pathology existed independently and that no more than one pathology coexisted in one organ. Inferring from the previously reported cases, LCH, PTC and $\mathrm{CD}$ may be closely linked disease entities or may be considered as part of the spectrum of syndromic disease. It is necessary to consider multicentric CD variants or multisystem $\mathrm{LCH}$ variants when accompanied by PTC, LCH and CD in the same organ or other distant organ synchronously/metachronously.

Treatment should be administered as per each disease entity. In the present case, the patient was treated on the basis of single-system LCH, PTC and multicentric CD. For PTC without metastasis, he only underwent surgical total resection and was monitored without adjuvant radioactive iodine ablation. For single-system low-risk organ $\mathrm{LCH}$, he only underwent surgical total resection and was monitored without adjuvant therapy. For multicentric CD with PC variants, he got three cycles of the 
Table 1 Summary of cases with coexisting LCH, PTC and/or CD reported in the literature

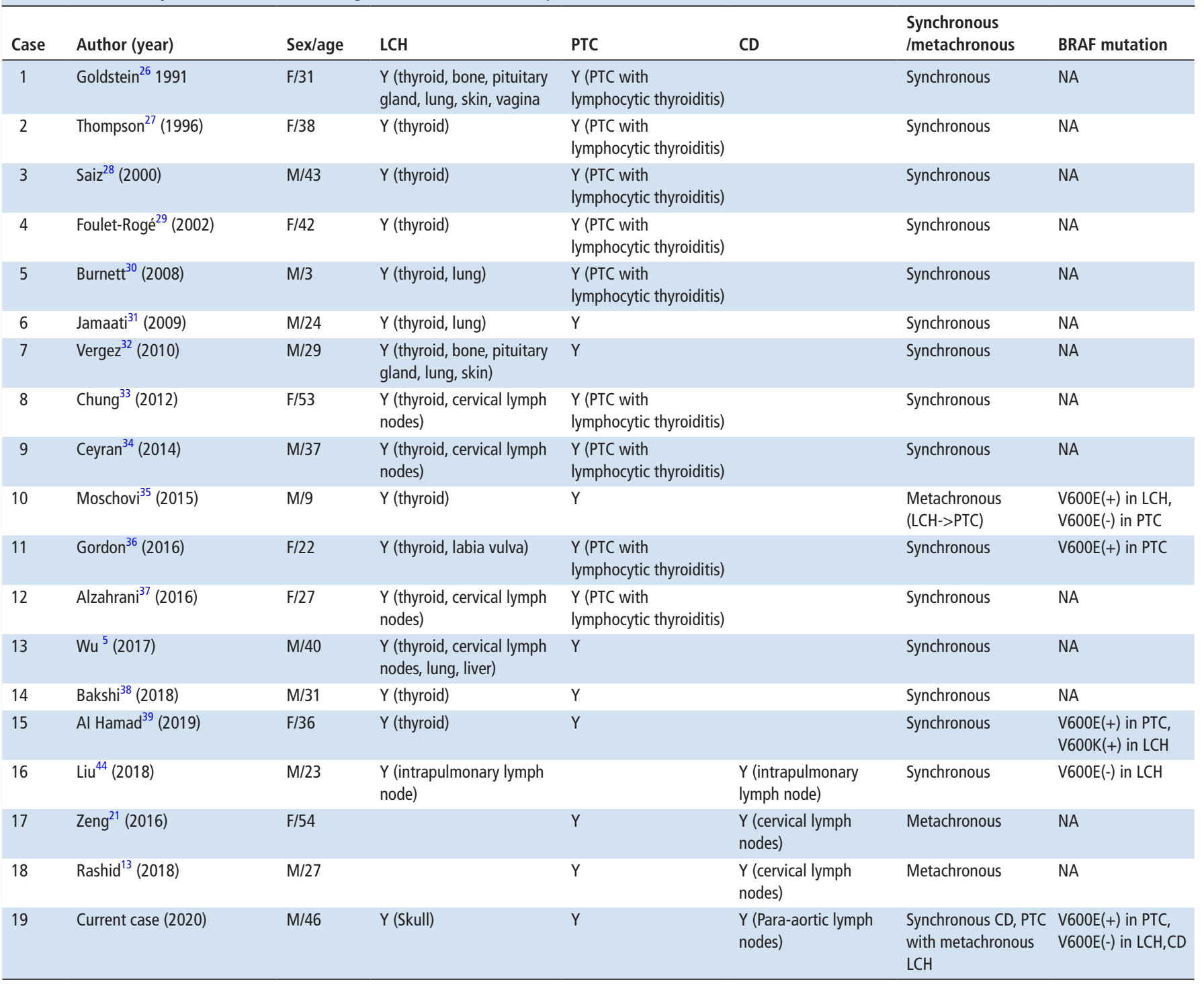

CD, Castleman disease; F, female; LCH, Langerhans cell histiocytosis; M, male; NA, not available; PTC, papillary thyroid carcinoma; Y, yes.

siltuximab (anti IL-6 antibody). At the 25-month follow-up, all three diseases had remained stable without any recurrence or progression. PTC has favourable prognosis. ${ }^{5}$ If PTC coexists with $\mathrm{LCH}$ or $\mathrm{CD}$, survival rates are expected to depend on the stage of LCH or CD than on PTC. The 5 -year survival rate (YSR) of single-system low-risk organ $\mathrm{LCH}$, such as in the patient in the present case report, is $>90 \%{ }^{41}$; the 5 -YSR in those with stage III (age $>45 \mathrm{y}$, T3N0M0) PTC is reported to be $82 \%$.

\section{Learning points}

- Our extremely rare case of metachronous skull LCH in adult patient with coexisting PTC and CD suggests syndromic nature of these diseases.

- Large-scale studies should be conducted to achieve a deeper understanding of the pathogenesis of cross-occurrence of these diseases.

- We need to establish a treatment strategy via early histological diagnosis with systemic staging to enhance patient management and improve survival.
Although controversial, BRAF mutation in PTC is reported to be a poor prognostic factor for overall survival (OS) or disease-free survival (DFS). ${ }^{42}$ Therefore, the OS and prognosis of the current patient were believed to depend on the control of multicentric CD. Multicentric CD has a 5 -YSR of about $51 \%$; in case of patients without an HIV infection, the 3 -year DFS is reported to be $46 \%$ in those with PC-type. ${ }^{43}$ Further, this disorder appears to be associated with poor prognosis in those aged $>40$ years, PC mixed histological type, and splenomegaly, as in this patient.

Acknowledgements The authors would like to thank Enago (www.enago.co.kr) for the English language review.

Contributors Conceptualisation: IKK. Data curation: IKK. Formal analysis: IKK and KYL. Funding acquisition: IKK. Investigation: IKK and KYL. Methodology: IKK. Project administration: IKK. Resources: IKK. Software: IKK. Supervision: IKK. Validation: IKK. Visualisation: IKK. Roles/writing-original draft: IKK. Writing-review and editing: IKK.

Funding The authors have not declared a specific grant for this research from any funding agency in the public, commercial or not-for-profit sectors.

Competing interests None declared.

Patient consent for publication Not required.

Provenance and peer review Not commissioned; externally peer reviewed. 
Open access This is an open access article distributed in accordance with the Creative Commons Attribution Non Commercial (CC BY-NC 4.0) license, which permits others to distribute, remix, adapt, build upon this work non-commercially, and license their derivative works on different terms, provided the original work is properly cited and the use is non-commercial. See: http://creativecommons.org/ licenses/by-nc/4.0/.

\section{ORCID ID}

In Kyeong Kim http://orcid.org/0000-0002-7761-9456

\section{REFERENCES}

1 Stockschlaeder M, Sucker C. Adult Langerhans cell histiocytosis. Eur J Haematol 2006:76:363-8

2 Favara BE, Feller AC, Pauli M. Contemporary classification of histiocytic disorders. The who Committee on Histiocytic/Reticulum cell proliferations. .Med Pediatr Oncol 1997.

3 Kim SS, Hong SA, Shin HC. Adult Langerhans' cell histiocytosis with multisystem involvement A case report. Med 2018;97.

4 Zhang X, Rao H, Xu X, et al. Clinical characteristics and outcomes of Castleman disease: a multicenter study of 185 Chinese patients. Cancer Sci 2018;109:199-206.

5 Wu X, Chen S, Zhang L-yang, et al. Langerhans cell histiocytosis of the thyroid complicated by papillary thyroid carcinoma. Medicine 2017;96:e7954:5-8.

$6 \mathrm{Kim}$ SJ, Lee J, Soh EY. The clinical significance of the BRAF mutation in patients with papillary thyroid cancer. J Endocr Surg 2017;17:175.

7 Kebebew E, Weng J, Bauer J, et al. The prevalence and prognostic value of BRAF mutation in thyroid cancer. Ann Surg 2007;246:466-71.

8 Olson $\mathrm{E}$, Wintheiser $\mathrm{G}$, Wolfe $\mathrm{KM}$, et al. Epidemiology of thyroid cancer: a review of the National cancer database, 2000-2013. Cureus 2019;11:e4127.

9 Edition S. AJCC cancer staging manual. AJCC cancer staging manual, 2017.

10 Girschikofsky M, Arico M, Castillo D, et al. Management of adult patients with Langerhans cell histiocytosis: recommendations from an expert panel on behalf of Euro-Histio-Net. Orphanet J Rare Dis 2013;8:72.

11 Bank Ml, Rengtved P, Carstensen H, et al. Langerhans cell histiocytosis: an evaluation of histopathological parameters, demonstration of proliferation by Ki-67 and mitotic bodies. APMIS 2003;111:300-8.

12 Castleman B, Iverson L, Menendez VP. Localized mediastinal lymphnode hyperplasia resembling thymoma. Cancer 1956;9:822-30.

13 Rashid N, Hassan A, Akhter N, et al. Castleman disease: a great MIMICKER of metastases in radioiodine refractory thyroid cancer. J Cancer Allied Spec 2018;4:4-7.

14 Talukder DY, Delpachitra SN. Multicentric Castleman's Disease in a Hepatitis C-Positive Intravenous Drug User: A Case Report. Case Rep Med 2011;2011:1-4.

15 Koreishi AF, Saenz AJ, Arcila ME, et al. Synchronous follicular lymphoma, Kaposi sarcoma, and Castleman's disease in a HIV-negative patient with EBV and HHV-8 coinfection. Int J Surg Pathol 2011;19:685-91.

16 Chen C-J, Ho T-Y, Lu J-J, et al. Identical twin brothers concordant for Langerhans? cell histiocytosis and discordant for Epstein-Barr virus-associated haemophagocytic syndrome. Eur J Pediatr 2004;163:536-9.

17 Moghoofei M, Mostafaei S, Nesaei A, et al. Epstein-Barr virus and thyroid cancer: the role of viral expressed proteins. J Cell Physiol 2019;234:3790-9.

18 Homayouni M, Mohammad Arabzadeh SA, Nili F, et al. Evaluation of the presence of Epstein-Barr virus (EBV) in Iranian patients with thyroid papillary carcinoma. Pathol Res Pract 2017:213:854-6.

19 van Rhee F, Stone K, Szmania S, et al. Castleman disease in the 21st century: an update on diagnosis, assessment, and therapy. Clin Adv Hematol Oncol 2010;8:486-98

20 Sevilla-Lizcano DB, Frias-Soria CL, Ortiz-Hidalgo C. Análisis histopatológico E inmunohistoquímico de treinta Y nueve casos. Gac Med Mex 2017;153:550-8.

21 Zeng $\mathrm{Y}-\mathrm{H}$, Chen $\mathrm{C}-\mathrm{K}$, Lee $\mathrm{C}-\mathrm{C}$. Castleman disease mimicking nodal recurrence of thyroid cancer. Endocrine 2016;51:384-6.
22 Fetica B, Pop B, Lisencu C, et al. Castleman disease. A report of six cases. Clujul Med 2014:87:192-7.

23 Menke DM, DeWald GW. Lack of cytogenetic abnormalities in Castleman's disease. South Med J 2001:94:472-4.

24 Frizzera G, Peterson BA, Bayrd ED, et al. A systemic lymphoproliferative disorder with morphologic features of Castleman's disease: clinical findings and clinicopathologic correlations in 15 patients. J Clin Oncol 1985;3:1202-16.

25 Hall PA, Donaghy M, Cotter FE, et al. An immunohistological and genotypic study of the plasma cell form of Castleman's disease. Histopathology 1989;14:333-46.

26 Goldstein N, Layfield LJ. Thyromegaly secondary to simultaneous papillary carcinoma and histiocytosis X. Report of a case and review of the literature. Acta Cytol 1991:35:422-6.

27 Thompson LD. Langerhans cell histiocytosis isolated to the thyroid gland. Eur Arch Otorhinolaryngol 1996;253:62-5.

28 Saiz E, Bakotic BW. Isolated Langerhans cell histiocytosis of the thyroid: a report of two cases with nuclear imaging-pathologic correlation. Ann Diagn Pathol 2000:4:23-8.

29 Foulet-Rogé A, Josselin N, Guyetant S, et al. Incidental Langerhans cell histiocytosis of thyroid: case report and review of the literature. Endocr Pathol 2002;13:227-33.

30 Burnett A, Carney D, Mukhopadhyay S, et al. Thyroid involvement with Langerhans cell histiocytosis in a 3-year-old male. Pediatr Blood Cancer 2008;50:726-7.

31 Jamaati HR, Shadmehr MB, Saidi B, et al. Langerhans cell histiocytosis of the lung and thyroid, co-existing with papillary thyroid cancer. Endocr Pathol 2009;20:133-6.

32 Vergez S, Rouquette I, Ancey M, et al. Langerhans cell histiocytosis of the thyroid is a rare entity, but an association with a papillary thyroid carcinoma is often described. Endocr Pathol 2010;21:274-6.

33 Chung DH, Ha SY, Cho HY, et al. Langerhans cell histiocytosis in the thyroid and draining lymph nodes: a case report. Endocrinol Metab 2012;27:138.

34 Ceyran AB, Senol S, Bayraktar B, et al. Langerhans cell histiocytosis of the thyroid with multiple cervical lymph node involvement accompanying metastatic thyroid papillary carcinoma. Case Rep Pathol 2014;2014:1-5.

35 Moschovi M, Adamaki M, Vlahopoulos S, et al. Synchronous and metachronous thyroid cancer in relation to Langerhans cell histiocytosis; involvement of $\mathrm{V} 600 \mathrm{E}$ BRAF-mutation? Pediatr Blood Cancer 2015:62:173-4.

36 Gordon MS, Gordon MB. Occult Langerhans cell histiocytosis presenting with papillary thyroid carcinoma, a thickened pituitary stalk and diabetes insipidus. Case Rep Endocrinol 2016;2016:1-3.

37 AlZahrani R, Algarni M, Alhakami H, et al. Thyroid Langerhans cell histiocytosis and papillary thyroid carcinoma. Gland Surg 2016;5:537-40.

38 Bakshi J, Kiran J. Langerhans cell histiocytosis co-existing with papillary carcinoma of thyroid - a rare surgical challenge. ARC J Cancer Sci 2018;4:5-8.

39 A. Al Hamad M, Albisher HM, Al Saeed WR, et al. Braf gene mutations in synchronous papillary thyroid carcinoma and Langerhans cell histiocytosis coexisting in the thyroid gland: a case report and literature review. BMC Cancer 2019;19:1-6.

40 Héritier S, Emile J-F, Barkaoui M-A, et al. Braf mutation correlates with high-risk Langerhans cell histiocytosis and increased resistance to first-line therapy. J Clin Oncol 2016;34:3023-30.

41 Aricò M, Girschikofsky M, Généreau T, et al. Langerhans cell histiocytosis in adults. Report from the International registry of the histiocyte Society. Eur J Cancer 2003:39:2341-8.

42 Li J, Zhang S, Zheng S, et al. The BRAF V600E mutation predicts poor survival outcome in patients with papillary thyroid carcinoma: a meta analysis. Int J Clin Exp Med 2015;8:22246-53.

43 Talat N, Schulte K-M. Castleman's disease: systematic analysis of 416 patients from the literature. Oncologist 2011;16:1316-24.

44 Liu X, Liu L, Zhang L, et al. A case of unicentric Castleman disease and Langerhans cell histiocytosis: two entities in one lymph node. Clin Lab 2018;64.

Copyright 2021 BMJ Publishing Group. All rights reserved. For permission to reuse any of this content visit

https://www.bmj.com/company/products-services/rights-and-licensing/permissions/

BMJ Case Report Fellows may re-use this article for personal use and teaching without any further permission.

Become a Fellow of BMJ Case Reports today and you can:

- Submit as many cases as you like

- Enjoy fast sympathetic peer review and rapid publication of accepted articles

- Access all the published articles

- Re-use any of the published material for personal use and teaching without further permission

Customer Service

If you have any further queries about your subscription, please contact our customer services team on +44 (0) 2071111105 or via email at support@bmj.com.

Visit casereports.bmj.com for more articles like this and to become a Fellow 